\title{
Is there Freedom of Expression of Morals of Reproductive Health in Medical School
}

\author{
Lynda M Khouzam* \\ Volunteer Faculty Pediatrics, USA.
}

\section{Commentary}

ISSN: 2640-9666

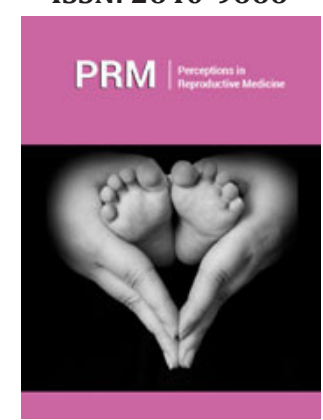

*Corresponding author: Lynda M Khouzam, MD,MPH, FAAP. Volunteer Faculty Pediatrics, USA.

Submission: 笽July 05, 2019

Published: 醖September 06, 2019

Volume 3 - Issue 4

How to cite this article: Lynda M Khouzam. Is there Freedom of Expression of Morals of Reproductive Health in Medical School. Perception in Reproductive Medicine.3(4). PRM.000567.2019.

DOI: 10.31031/PRM.2019.03.000567

Copyright@ Lynda M Khouzam, This article is distributed under the terms of the Creative Commons Attribution 4.0 International License, which permits unrestricted use and redistribution provided that the original author and source are credited.
It was after an exchange with a medical student about why she was so passionate about finding a residency that offered training in abortions, that I was asked to "part ways" from the class where I was a volunteer faculty. In an after class setting, this student, freely and cheerfully expressed to me her family "heritage" of abortions, and that she had also exercised her right to choose the same. I had suggested she consider that women post abortion weeks or years later may suffer grief after their abortion. She vehemently expressed "that doesn't happen." A few weeks later, I was asked to see the director of the program and questioned about my position on abortion. My response was and is, that I believe in the sanctity of life. The IOR adamantly pointed out that in this state, abortion is legal, that it is a fetus when in utero, and that the term "baby" is reserved for the moment of delivery. I acknowledged his explanation, but a few weeks later was asked to not continue in the program, and that personal contact with the group would be an "awkward" situation but emailing my goodbye would be acceptable.

In our medical culture today, "patient autonomy "and normalizing the request for abortion on demand is a guiding paradigm. As one of the medical students stated in their email to me in response to my removal from the class, "we are in an indoctrination camp", not encouraged to challenge the status quo but accept the course doctrine. In medical school students learn that modern molecular biology proves life is present from the moment of conception [1]. Advances in diagnosis and treatment establish the fetus as a patient of value with full moral standing, and that a human being develops from a newly fertilized ovum to pre-embryo, embryo, fetus, newborn baby and to an autonomous person with full moral standing including a moral and legal right not to be killed. We have changed drastically from the Hippocratic code "I will maintain the utmost respect for human life, from the time of conception" [1].

The Liason Committee on Medical Education (LCME) stated goals are to instill in its graduates, "values consistent with a compassionate professional" and to employ "scrupulous ethical principles" in caring for patients [2]. In modern medicine, this must include compassion, support, listening to the concerns, and for the pregnant woman, offering an ultrasound, which would show that the conceptus is more than a "blob of tissue". This would allow discussion of options for the mother in a crisis pregnancy, to reassess her fetus which is in the developing stages of becoming a person of value. Although medical school "normalizes" the "choice" of abortion for those who seek it, "A key component of clinical training is to promote a reflective practitioner" [3]. So, by allowing students and faculty open discussion the fetus rights to life allows both to reflect on their convictions and values. "The science of ethics will always console for the ignorance of the physical science," Blaise Pascal [1].

\section{References}

1. Alka B Patil, Pranil D, Amruta A (2014) Medical ethics and abortion. Indian Journal of Clinical Practice 25(6): 544-548.

2. Frederick H (1998) Beyond Curriculum. Academic Medicine 73: 407.

3. Ramani S, Krackov SK (2012) Twelve tips for giving feedback effectively in the clinical environment. Med Teach 34(10): 787-791.

For possible submissions Click below: 